\title{
RELIQUIAS Y RELICARIOS: UNA APROXIMACIÓN AL ESTUDIO DEL CULTO A LOS SANTOS EN LA NAVARRA MEDIEVAL
}

\author{
POR \\ ÁNGELES GARCÍA DE LA BORBOLLA \\ GARCÍA DE PAREDES \\ Departamento de Historia, Historia del Arte y Geografía \\ Universidad de Navarra
}

\section{RESUMEN}

Las reliquias, que a primera vista son pequeños recuerdos materiales o físicos de un personaje santo, despertaron en el Occidente medieval unos sentimientos religiosos sustentados sobre unas creencias colectivas. Al mismo tiempo, esa fe y piedad impulsaron también un deseo y afán por poseerlas, acumularlas y custodiarlas en los principales centros religiosos del momento. En esta ocasión se presentarán los casos más sobresalientes del reino de Navarra en los siglos medievales.

\section{PALABRAS CLAVES}

Reliquias; culto a los santos; espiritualidad medieval; Navarra Edad Media.

\section{RELICS AND RELIQUAIRES: AN APPROACH TO THE STUDY OF THE CULT OF SAINTS IN MEDIEVAL NAVARRE}

\section{ABSTRACT}

In medieval Europe, relics, which are small material or physical objects conserved as a way of remembering a holy person, aroused religious sentiments that resonated with people's collective beliefs. At the 
same time, this faith and piety also inspired a desire to possess relics, to collect them and keep them safe in the main religious centres of the time. This paper describes the most outstanding relics in the medieval kindgom of Navarre.

\section{KEYWORDS}

Relics; cult of saints; medieval spirituality; Navarre Middle Age.

$\begin{array}{ll}\text { Recibido/Received } & \text { 05-02-2013 } \\ \text { Aceptado/Accepted } & 25-04-2014\end{array}$

Durante la Edad Media cuando el fiel cristiano dirigía su plegaria a Dios, como único dispensador de todo bien, también conocía perfectamente los canales que tenía a su alcance para obtener el favor divino. Existían una serie de personajes mediadores que resultaban ser más accesibles, sobre todo en el caso de los santos pues eran más próximos, dada su condición humana, aunque gracias a sus méritos terrenos participaban de extraordinarias gracias divinas. El hombre medieval no pone en duda la existencia de una perfecta comunicación entre el mundo celestial y terrenal, garantizada en cierto sentido por toda una galería de santos mediadores. Del mismo modo, no le suponía un gran problema estar separado por una distancia de siglos de los santos a los que suplicaba, aunque en este sentido uno de los elementos que lograba anular esa distancia temporal y física eran las reliquias. ${ }^{1}$

La arraigada devoción hacia estos "tesoros", mantenida a lo largo de toda la Edad Media, es sin duda una de las principales manifestaciones del culto a los santos. Las reliquias eran aquellos preciosos objetos que recibían la veneración de los fieles y cuya eficacia milagrosa se demostraba mediante los milagros. En este sentido las

${ }^{1}$ García de la Borbolla, A. 2001. "La materialidad eterna de los santos. Sepulcros, reliquias y peregrinaciones en la hagiografía castellano-leonesa. Siglo XIII". Medievalismo. Boletín de la Sociedad Española de Estudios Medievales. 11: P. 9-31. Y García de la Borbolla, A. 2002. La praesentia y la virtus de los santos en el mundo medieval: la imagen y función del santo a partir de la hagiografía castellano-leonesa del siglo XIII: 206-220 Abadía de Silos Burgos: Studia Silensia, XXIV. Vid. Pérez-Embid, J. 2002. Hagiología y sociedad en la España Medieval. Castilla y León (siglos XI-XIII). Universidad de Huelva; Fernández catón, JM. 2003. "El culto de las reliquias: crítica hagiográfica, fuentes e historia". Memoria Ecclesiae. 24. 
reliquias son los instrumentos materiales, visibles y tangibles mediante los cuales se manifiesta la Omnipotencia divina. Además a nivel cultual serán otros de los resortes que sostienen la certeza de un intercesor próximo a un nivel más perceptible, y a pesar del carácter sorprendente de algunas de ellas, no cabía el escepticismo entre los fieles devotos que no evidenciaban ningún signo de preocupación científica ante la veracidad de la misma. Por el contrario, en este campo la fe se aproximaba a la credulidad, y no contaba con los límites que imponen las explicaciones racionales del hombre actual.

Esta devoción a las reliquias nace en Oriente pero ahí no conoció la importancia que adquiere en Occidente, donde se asiste a una progresiva unión del aspecto material al culto divino que termina siéndole inherente. La piedad occidental, menos trascendental que la oriental, se presenta más sensible a la naturaleza humana de Cristo, y por lo tanto, más unida a los recuerdos materiales que Jesús, la Virgen María y los santos dejaron sobre la tierra. ${ }^{2}$ Estos objetos no pueden ser considerados como simples despojos materiales o recuerdos personales, ni como los restos mortales de un personaje insigne. Su valor trasciende esos parámetros pues la santidad indiscutible de estos personajes venerados implicaba que todo lo que había estado en contacto con él quedaba sacralizado por la emanación de su virtus. De este modo, la reliquia debe ser entendida como la presencia real e ininterrumpida del santo entre los fieles. De ahí la honra con la que se veneran, el respeto que reciben, el afán por poseerlas y el celo por conservarlas, pues se trata de unos objetos de culto que son eficaces y poderosos salvaguardas espirituales.

En las páginas siguientes intentaremos ofrecer una visión de conjunto sobre la devoción y el culto a las reliquias en la Navarra medieval, partiendo de aquellas de las que tenemos constancia documental. Se han tenido en cuenta los testimonios escritos, principalmente inventarios conservados, fuentes literarias como los relatos hagiográficos 0 narraciones históricas sobre el uso de determinadas reliquias, así como de todos aquellos objetos materiales y artísticos que las contenían: los relicarios. No obstante, y dadas las características de este trabajo hemos descartado un estudio artístico de estas magníficas piezas que en muchos de los casos ya han sido analizadas y catalogadas por expertos. En este sentido, cabe señalar que en la abundante bibliografía sobre las reliquias y los relicarios, estos últimos son tratados exclusivamente desde el punto de vista de la historia

2 Herrman-Mascard, N. 1975. Les reliques des saints. La formation coutumière de un droit . 18 París, Klincksieck. 
del arte. ${ }^{3}$ Sin embargo, nuestro interés hacia los relicarios se debe a su carácter de contenedores de reliquias, y por lo tanto a su participación de la virtus, dado el contacto que han mantenido con el sagrado contenido y que incluso se mantiene una vez está vacío de su sagrado objeto. Dada la profusión de estos tesoros por el solar del reino nos hemos permitido realizar una selección entre las reliquias que tradicionalmente se consideran más significativas y que arraigaron más en la devoción popular durante los siglos medievales.

Esta selección nos permite trazar a grandes rasgos la evolución en el reino de Navarra del culto a los santos durante el periodo medieval. Aunque lógicamente el análisis pormenorizado de la veneración que recibe cada una de ellas a lo largo de los siglos medievales en el solar del reino requiere de trabajos individuales o de un volumen mayor de páginas. De modo que lo que vamos a exponer a continuación como el propio título indica es una primera aproximación que relaciona los tesoros artísticos de un reino con la evolución espiritual del mismo.

En cuanto a la exposición el trabajo se desarrolla teniendo en cuenta la evolución del culto a los santos a lo largo de las centurias medievales. Así partimos del culto martirial y episcopal de los siglos altomedievales a la devoción cristológica del final del periodo estudiado. Una división clara y sencilla que pretende articular de manera ordenada el trabajo siguiendo unos parámetros cronológicos y tradicionales.

\section{LAS RELIQUIAS DE VÍRGENES Y MÁRTIRES}

Durante los primeros siglos medievales el antiguo reino de Pamplona, al igual que podía ocurrir con cualquier otro punto de la Europa medieval, presenta claramente desarrollado uno de los exponentes de la cultura religiosa medieval: el culto a los santos. En estas tierras navarras pueden rastrearse los comienzos de muchas advocaciones en el arco temporal que va del siglo $\mathrm{V}$ al VIII. Este dato viene a reforzar si cabe aún más la idea de una sociedad que desde época romano-cristiana está inscrita en la civilización europea occidental con un marcado sello cristiano.

${ }^{3}$ Sirvan como referencia los siguientes estudios de Heredia Moreno, COrbe, M., 1986. Orfebrería medieval navarra, tomo I, Edad Media. Pamplona: Caja de Ahorros de Navarra. Y de Martínez de Aguirre, J. 2000. "Los relicarios góticos del santo Sepulcro (siglo XIII) y de la santa Espina (XV) de la catedral de Pamplona». Príncipe de Viana, 63: 295-325. Martínez de Aguirre, J. 2007. "Platería medieval en la catedral de Pamplona según un inventario de 1511". Anales de Historia del Arte 17: 71-84. 
En este contexto la posesión y glorificación de reliquias han sido poderosos estimulantes de fenómenos cultuales. Estos sagrados objetos comienzan a proliferar en las consagraciones de altares o en los tesoros de los principales cenobios del reino. Y sin duda durante los siglos de la Alta Edad Media las reliquias más reclamadas eran las de los mártires.

La figura del mártir es el punto inicial del culto a los santos y es a partir del siglo III cuando la Iglesia occidental comienza a celebrar la memoria de aquellos que siguiendo a Cristo ofrecen su vida en testimonio de la verdad, y afirman con su muerte que Dios es lo único verdaderamente necesario (Mc. 8, 36). Los primeros escritores eclesiásticos presentaban al mártir como el cristiano perfecto, el imitador de Cristo y de los apóstoles, el alma pura por excelencia. ${ }^{4}$ En un principio, cada comunidad honraba a sus propios mártires, pero desde mediados del siglo IV, los martirologios locales se ven enriquecidos con aportaciones de mártires extranjeros. El aniversario del mártir, dies natalis, era una solemnidad religiosa, y correspondía al día de su muerte pues significaba su nacimiento a la vida eterna. El primitivo espacio cultual solía situarse próximo a su tumba, donde se levantarán las primeras basílicas, ya que por la influencia de la legislación romana quedaba prohibida la profanación de tumbas, impidiéndose de este modo la traslación de las reliquias. En estos lugares consagrados se celebraban vigilias de plegarias junto con el sacrificio eucarístico que se constituirá en el rito oficial de la conmemoración del martirio. ${ }^{5}$

Sin embargo, a partir del siglo VII se introduce una nueva práctica que ratifica públicamente la santidad. Se trata de la elevatio, o exhumación del cadáver, seguida de una traslación del cuerpo a una sepultura más digna. Además si al abrir la antigua sepultura el cuerpo no se encontraba en ese estado tan extraordinario y sorprendente como era la incorruptibilidad, se podía proceder a la dismembratio del cuerpo, una práctica frecuente en Oriente desde el siglo IV y por la que se consideraba que la eficacia de la parte respecto al todo era idéntica, al igual que ocurre con la sagrada Hostia. ${ }^{6}$

4 Delehaye, H. 1933. Les origines du culte des martyrs. Bruselas: Societé des Bollendistes.

${ }^{5}$ Chiovaro, F. 1986, Histoire des saints et de la sainteté. París: Hachette. 11 vols.

${ }^{6}$ García Rodríguez, C. 1966, El culto a los santos en la España romana y visigoda. 365, Madrid: CSIC. "Es cierto que en un primer momento hubo cierta resistencia a la fragmentación de los cuerpos. Así en el caso peninsular, en la Passio Fructuosi, el santo hace una llamada a los cristianos de la Tarraconense para que devuelvan las pequeñas reliquias que se habían llevado. Posteriormente y desde el siglo $\mathrm{VI}$ se impone en la Península la costumbre de consagrar las iglesias con reliquias lo cual provocará un incremento considerable de las mismas". 
Generalmente, una vez abierto el sepulcro se solían encontrar dispersos los restos óseos que eran recogidos con suma veneración y respeto, y que se introducían en pequeños recipientes de piedra, de metal o de barro. Esto supuso la multiplicación de reliquias de los primeros mártires que llegan hasta los más recónditos lugares de Europa. Por otro lado muy pronto se desarrolló una tendencia a concentrar estos valiosos tesoros espirituales en los centros religiosos pues contribuían en muchos casos a reavivar el prestigio de una comunidad, de un santuario o de una diócesis.

Desde el punto de vista cultual las reliquias se solían acumular no sólo en el tesoro de la iglesia sino también en el mismo relicario, y ajustada a esta práctica encontramos nuestra primera referencia: la imagen relicario de la Virgen titular de la diócesis de Pamplona. Se trata de la imagen mariana más antigua existente en Navarra anterior a la década 1175-85. Según parece la devoción a la Madre de Dios arraigó hondamente entre las gentes de Pamplona a lo largo del siglo XI, y monarcas como Sancho el Mayor contribuyó a la restauración de la sede y a la reconstrucción del que sería el primer templo diocesano dedicado a la Asunción. No obstante, a finales de esa centuria el primitivo templo será destruido y sobre sus ruinas se elevará la primera catedral románica bajo el obispado de don Pedro de Roda. ${ }^{7}$ A partir de entonces, los reyes y los fieles multiplicarán sus donaciones a santa María de Pamplona.

En el caso de la Virgen de la catedral estamos ante una imagen relicario, al igual que el de santa María de Tudela (1180-1190), aunque en este último caso los fragmentos de tela encontrados en su interior no llevaban identificación alguna que haya permitido esclarecer de qué reliquias se trataba. En cuanto al uso de este tipo de imágenes la profesora Clara Fernández Ladreda supone que por un lado contribuían, gracias a la presencia de reliquias, a un culto a las imágenes que no pudiera ser atacado de idolatría por parte del alto clero catedralicio. Pero al mismo tiempo la presencia de reliquias en una talla otorgaba gran prestigio tanto a la imagen como al santuario al que pertenecía. En el caso navarro son las dos titulares de las sedes catedralicias de sus respectivas diócesis, Pamplona y Tudela, las que contienen reliquias en su interior aspirando por lo tanto a la supremacía espiritual. Sin embargo, el hecho de que no tengamos más ejemplos en Navarra puede deberse

7 Goñi Gaztambide, J. 1979, Historia de los obispos de Pamplona, Pamplona, I, 254-314. Vid. Goñi Gaztambide, J. 1994, "La veneración a santa María la Real", La Catedral de Pamplona, I, 25-33. Pamplona: Caja de Ahorros de Navarra. 
también al costo de las reliquias cuya adquisición no estaba al alcance de cualquier comunidad religiosa. ${ }^{8}$

De este modo en la cabeza de la imagen de la Virgen iruñesa se abre un compartimento destinado a guardar las reliquias y que es coetáneo a la labra de la escultura. El testimonio escrito más antiguo sobre las reliquias contenidas es de 1511, año en el que se inventariaron y se incluyeron algunas más, aunque al parecer existió otro inventario anterior del año 1378. De este modo a comienzos del siglo XVI y tal como señala el pergamino original el capellán real realizó una exploración en esta cavidad y localizó numerosas reliquias, acompañadas por su identificación escrita. Las reliquias inventariadas no son exclusivamente marianas, que son pocas (un trozo del vestido de la Virgen), sino que en su mayoría son de santos vinculados a la tradición local como san Saturnino o Nunilo y Alodia y otros personajes veterotestamentales como Daniel y Macabeos. Pero lo que destaca en el conjunto es la numerosa presencia de las reliquias de mártires: san Irineo, San Ciriaco, san Cosme y Damián, san Inocencio, san Tiburcio, san Valeriano, santa Cirila, san Jorge, san Mauricio, san Vital, san Esteban, san Pristo, san Nazario y san Celso, san Agapito, san Lorenzo, San Sebastián, Santa Cristina, san Luperto, san Desidero, santos Justo y Pastor, san Felices Jupincio, san Felix y san Audacio, Santa Lucía, santa Eulalia, santa Eulalia de Barcelona, santos Emeterio y Celedonio, santa Cecilia y santa Inés. ${ }^{9}$

La progresiva distribución o dispersión de las reliquias describen un "universo de lo sagrado" que estaba perfectamente localizado en unas coordenadas espaciales, que en el caso del primitivo reino de Pamplona tenían como eje más destacado el monasterio benedictino de san Salvador de Leire. Tal y como era habitual, los núcleos monásticos más pujantes se esforzaban por legitimar su espacio sagrado y ser polos de atracción de fieles, dentro de un ámbito local o "universal". Un fin al que contribuía en gran medida tanto la posesión de reliquias como que se conociera el poder sobrenatural de ellas, en especial su virtus taumatúrgica. La posesión de reliquias implicaba consecuencias muy ventajosas pues suponía contar con una devoción estable y en cierto sentido garantizarse la afluencia de fieles peregrinos que suplicaban el favor del santo. Este hecho se traducía a efectos prácticos en una constante vía de ingresos necesaria para el mantenimiento y la continuidad de este núcleo de vida de oración.

${ }^{8}$ Fernández Ladreda, C. 1988, Imaginería medieval mariana, p. 53-56, Pamplona: Gobierno de Navarra.

${ }^{9}$ Archivo de la Catedral de Pamplona. "Arca Thesaurarii", n. 10. 
A este esquema se ajusta el monasterio de san Salvador de Leire, un espacio de particular referencia en la historia del reino pues fue elegido como lugar de enterramiento por los monarcas pamploneses. Los primeros testimonios documentales del cenobio corresponden al siglo IX, pero sin duda su época de esplendor se alcanza en el siglo XI con Sancho el Mayor (1004-1035) y sus sucesores, quienes se ocuparon de incrementar considerablemente el patrimonio de este centro gracias a sus numerosas donaciones. ${ }^{10}$ Durante esta centuria sus abades eran al mismo tiempo los primados de la sede pamplonesa, dato bastante significativo a la hora de demostrar el prestigio del centro monástico. Además bajo este monarca se introduce la reforma cluniacense y Leire se convierte en lugar de acogida de los peregrinos a Santiago. En el siglo XII su patrimonio se consolida con posesiones repartidas entre los reinos de Castilla, Aragón y Navarra, y en 1239 se introduce la reforma cisterciense.

Entre las reliquias más destacas que se custodiaban en este monasterio enclavado en el corazón de la sierra que hoy lleva su mismo nombre, se encuentran las de las vírgenes mártires Nunilo y Alodia. El 21 de octubre del año 851 ambas santas fueron ejecutadas en Huesca y al parecer sus martirios están estrechamente relacionados con la problemática martirial que sacudía a la capital del emirato. Según el Breviario de Leire sus reliquias fueron trasladadas hacia el año 880, aunque el relato de su traslación es mucho más tardío (finales del XI y comienzos XII). La razón de la traslatio al cenobio pamplonés quizás está en las victorias de Alfonso III sobre el emir cordobés (Polvararia y Valdemoro) quien tuvo que acceder a determinadas exigencias como la liberación de Fortún Garcés y su hija Oneca, prisioneros en Córdoba desde 860. Además consiguió la licencia para trasladar los restos mortales de estas dos santas al territorio cristiano más próximo y donde sin duda tuvieron más eco sus martirios: el reino de Pamplona.

De manera que el 18 de abril del año 880 se procede a la traslación de sus cuerpos que se depositan en el que, en estos momentos, parecía ser el santuario navarro más digno. A partir de entonces y con la recepción de tan preciados tesoros, el prestigio del monasterio experimentó un reforzamiento, consolidándose como polo de atracción de una devoción perpetuada durante siglos entre diferentes grupos sociales. El culto a estas mártires oscenses se pone de

${ }^{10}$ Fortún, L. J. 1983. Leire, un señorío monástico en Navarra (siglos XI$X I X)$ : 82-83, Pamplona: Gobierno de Navarra. Por una parte se cuenta con la donación realizada por Eneco Arista de la villas de Yesa y Benasa al abad Fortún el día de la traslación de las reliquias de las mártires Nunilo y Alodia (842). Y por otra, con la carta redactada desde Leire por san Eulogio al obispo de Pamplona en su viaje a los monasterios pirenaicos de Pamplona y Aragón (851) donde refiere la riqueza de los fondos de la biblioteca del monasterio. 
manifiesto en las numerosas invocaciones de las donaciones recibidas por el cenobio desde esa fecha, donde sus nombres aparecen junto a la advocación principal: San Salvador. Por otra parte, la documentación refleja el deseo de recibir sepultura ad sanctos, es decir próxima al lugar donde se encontraban las reliquias de las santas. Así por ejemplo, con motivo de la fundación de un aniversario de Sancho Abarca II, en memoria de su hermanastro Ramiro, que luce el título de rex como ocurría con todos los hijos de los reyes en la monarquía pamplonesa, se dispone de la donación al monasterio de las villas de Apardués y Navardún junto a otros bienes del difunto. Pero además en el documento se hace referencia al lugar de la sepultura, in hoc domo cum pace sepultus est, en este monasterio donde se custodian esos preciosos tesoros que son las reliquias de Nunilo y Alodia: ubi quiescunt corpora sanctarum hac virginum et martirum [Christi] Nunilois atque Alodie, necnon et omne reliquie beatissimorum apostolorum atque martirum qui ibidem recondite sunt per misericordiam domini nostri Ihesu Christi, amen. ${ }^{11}$

En Leire también descansaban los restos de otros santos como el abad Virila y el obispo Marcial, de los que hablaremos más adelante y que responden a los restantes arquetipos de santos, el santo obispo y el santo monje, que la Antigüedad cristiana había legado al mundo medieval. Todas ellas enriquecían el tesoro espiritual de este monasterio y contribuían a la difusión de un culto que irá más allá de los márgenes locales.

Pero hablar de reliquias de mártires y del reino de Navarra significa hacer referencia a las reliquias del santo copatrono de Navarra: san Fermín, titular de la diócesis de Pamplona. Según la tradición, elaborada tardíamente, a este santo que viviría en la Pamplona de la segunda mitad del siglo III, aunque la tradición local lo remonta al siglo I, se le atribuye la evangelización de Navarra.

Fermín era miembro de una familia senatorial y una vez convertido al cristianismo, siendo presbítero, fue ordenado obispo. Entonces se dirigió a la Galia donde actuará como misionero itinerante en algunas regiones como Aquitania, Auvernia, Anjou y finalmente la Picardía. En esta última zona, en la ciudad de Amiens será ejecutado por las autoridades romanas y recibirá sepultura en el lugar donde se erigió posteriormente la abadía de Saint-Acheul. Al parecer la invención del cuerpo de san Fermín ocurrió en el año 615 durante el pontificado de san

${ }^{11}$ Martín Duque, A. 1983. Documentación Medieval de Leire (siglos IXXII). Pamplona: Gobierno de Navarra. Docs. 9 y 11. García de la Borbolla, A y Pavón, J., 2007, Morir en la Edad Media: 217-218. Valencia: Universidad de Valencia. 
Salvio quien según la leyenda hagiográfica recibe la milagrosa revelación del lugar exacto donde se encontraban las reliquias. El 13 de enero de ese mismo año se lleva a cabo la traslación de sus restos mortales a la catedral de Amiens. Finalmente será en el siglo XII cuando el culto a este santo adquiera gran esplendor y popularidad en la ciudad francesa bajo el impulso del obispo Godofredo. A finales de este siglo (1180) las reliquias se trasladan a una caja de oro y piedras preciosas, una verdadera obra de arte de la orfebrería románica que fue destruida durante la revolución francesa. Y desde 1851 reposan en una arqueta regalada al obispo de Amiens por el duque de Norfolk.

En cuanto a Navarra, el culto a san Fermín tiene sus primeras huellas históricas en el siglo XII bajo el obispado de Pedro de Artajona o también llamado de París por su periodo de estudios en la ciudad francesa. En 1186 este obispo de Pamplona consiguió del prelado de Amiens, Teobaldo de Nelly, una reliquia del cráneo del santo que al parecer llegó en una cruz de oro. En ese mismo año el prelado dispuso que la festividad del santo se celebrase de ahí en adelante con mayor solemnidad, como se celebraban las fiestas de los apóstoles, duplicando el número de cantores en el coro. Además mandó al enfermero de la catedral que el día de la festividad del santo, que nació en Pamplona y de donde fue obispo, se ofreciera una comida especial a los canónigos de la cual el documento conservado en el archivo de la catedral de Pamplona detalla el menú consistente en carne de vaca y carneros, (salvo si fuese viernes que entonces se tomaría pescado), huevos, gallina y pan. Para su sostenimiento el obispo entregó al cabildo un huerto con sus diezmos. Este es el primer documento conocido con referencias claras a su culto y devoción en Pamplona. ${ }^{12}$

La devoción a las reliquias del santo se propagó rápido por la diócesis, en 1270 recibía culto en el altar de la catedral y en 1300 se celebraba su fiesta con octava solemne. Además a partir de 1407 se constata la existencia de una capilla dedicada al santo dentro de la parroquia de san Lorenzo erigida a finales del XIV, cuando la construcción de la nueva catedral gótica (1394) trajo la desaparición del altar dedicado al santo. Se entiende que para esas fechas su culto era tan importante que no podía quedar sin su correspondiente espacio. Finalmente, en 1446 el obispo de Pamplona preescribe en el sínodo diocesano la celebración de la octava de san Fermín en toda la diócesis. ${ }^{13}$

12 Goñi Gaztambide, J. 1997. Colección diplomática de la Catedral de Pamplona (829-1243). Doc. Enfermero, 2, 28. Pamplona: Gobierno de Navarra. Y Goñi Gaztambide, J. 1979, Historia de los obispos de Pamplona, 463.

13 Jimeno, R. 2003. El culto a los santos en la cuenca de Pamplona, siglos V-XVI, 243 Pamplona: Gobierno de Navarra. 
Por otro lado, es curioso comprobar como las reliquias de san Fermín no dejaron de llegar a la diócesis en los siglos venideros lo cual indica un culto y una devoción viva y dinámica. Así en 1386 Carlos II trae otra reliquia concedida por el obispo de Amiens y la deposita en la iglesia de san Lorenzo, aunque a comienzos del XVI se traslada a una especie de copón relicario en la catedral. Dos siglos más tarde en los años 1522, 1592 y 1595 vuelven a llegar reliquias, la primera para la casa Consistorial, la segunda para la capilla del santo y la tercera para la imagen. Pero quizás la más importante fue recibida en 1572 por doña Beatriz de Beaumont, hija de don Francisco capitán de la guardia de Felipe II. Esta se depositó en un relicario situado en el pecho de la imagen busto del santo ejecutada a finales del siglo XV y que se encontraba en la iglesia de san Lorenzo. En este mismo busto relicario se introduce una nueva reliquia en 1638. Con posterioridad, aparte de otras de menor importancia, cabe señalar la enviada en 1941 por el obispo de Amiens, Luciano Martín, en un relicario neogótico que se encuentra actualmente en la catedral de Pamplona. ${ }^{14}$

En este apartado de reliquias martiriales cabe hacer referencia a las reliquias de otro santo que contó con gran devoción en la localidad navarra de Estella. Se trata de san Andrés, patrón de esta villa. ${ }^{15}$ Estella era una nueva población radicalmente franca que como tal se documenta desde 1076-1084 aunque su fundación tradicionalmente se data en 1090. Sin duda el flujo migratorio ultrapirenaico articulado de manera notable por las rutas hacia Compostela contribuyó al nacimiento de un núcleo de población que recibió el sugerente nombre de Stella.

Cuenta la leyenda hagiográfica que hacia 1270 un obispo de la ciudad griega de Patras visitó la tumba del apóstol Andrés de la cual tomó una reliquia, un trozo del omoplato, con la intención de regalarla a la sede compostelana al final de su peregrinación. No obstante sabemos que desde 1267 a 1273 esa sede de la iglesia griega se encontraba vacante, por lo que la fecha inicial es inaceptable

${ }^{14}$ Arraiza Frauca, J. 2002. San Fermín, el santo, la devoción, la fiesta, 113 Pamplona: Ayuntamiento de Pamplona.

15 Iribarren, S. 1912. Apuntes sobre la historia antigua de Estella, 136 Sevilla: las Heras. San Andrés fue el primero de los doce discípulos en dejar su oficio de pescador y seguir a Jesús. Después de la muerte de Cristo, cuando los apóstoles se dispersaron por el mundo para predicar el Evangelio, Andrés recorrió Asia Menor, el Peloponeso, Tracia, Escitia, hasta el Mar Negro y el Cáucaso. Encontró su martirio en Patras, ciudad de Acaya, donde se presentó ante el prefecto y le aseguró que si conociera el misterio de la Cruz creería en Jesucristo. Estas palabras encolerizaron al prefecto, que lo condenó a morir en una cruz en forma de aspa. Su festividad se celebra el 30 de noviembre. El cuerpo del santo fue desmembrado en innumerables reliquias que se repartieron por la Cristiandad. 
históricamente. El relato continúa diciendo que el prelado viajó a Compostela como un peregrino cualquiera pero al llegar a Estella enfermó y murió sin que nadie conociera su verdadera identidad. De modo que según la leyenda fue sepultado de modo anónimo en el cementerio de la iglesia de san Pedro. Sin embargo, según la leyenda al poco tiempo el sacristán de la iglesia pudo ver como su tumba desprendía un gran resplandor. Entonces, avisadas las autoridades de la iglesia, se procedió a exhumar el cadáver que se encontró incorrupto y que además albergaba en su pecho la caja con una reliquia identificada por una nota como de san Andrés. ${ }^{16}$

Quizás lo más probable frente a esta leyenda es que la realidad histórica sobre el origen de la reliquia del apóstol se encuentre en algún cruzado o peregrino que visitó los santos Lugares. Pues la figura de san Andrés atrajo especialmente a todos aquellos que participaron en la primera cruzada a Tierra Santa. No obstante, este relato de la reliquia de san Andrés inspiró al desconocido artista que cincelo varias escenas de la vida del apóstol en los ocho capiteles del claustro románico de la iglesia de san Pedro de la Rúa de Estella y motivó la construcción de una capilla dedicada al santo. Su culto se impulsó a partir de 1373 gracias a la promoción de Carlos II, que fundó una capellanía perpetua en el altar del santo de esta parroquia. Curiosamente un momento en el que la iglesia parroquial atraviesa una difícil coyuntura económica. A partir de entonces la documentación ilustra el acrisolamiento de un culto en buena parte gracias a las aportaciones de los monarcas de la casa Evreux. De este modo, las reliquias, custodiadas en la iglesia de san Pedro, situada en el barrio más importante de la localidad, articulan las ceremonias de la festividad del santo a la que en varias ocasiones acuden los monarcas (procesión, misa mayor y sermón, limosnas e incluso un nuevo relicario).

Al parecer el monarca encargó a Miguel de Zuasti, célebre platero de Pamplona, que elaborara un relicario en oro y esmaltes con las armas reales que no se terminó hasta 1374 y que se vendió a comienzos del XVIII. Además el rey dispuso que el día de su festividad las gentes junto con todos los religiosos de la villa salieran en procesión por la ciudad llevando honradamente este relicario así como todas las demás reliquias que guardaba esta iglesia. Los relicarios serían rodeados por trece antorchas de cera portadas por trece pobres, a los que se manda vestir, alimentar y dar limosna, y las antorchas se utilizaría en la celebración solemne de la misa. Este privilegio lo confirma la princesa Leonor en 1467. Posteriormente en 1625 la villa

${ }^{16}$ Iribarren, S. 1912.136. 
navarra decidió reconocer solemnemente a San Andrés como patrono. $^{17}$

Esta misma localidad alberga en el interior de sus templos otras destacadas reliquias cuyos relicarios son en su mayoría piezas de orfebrería del siglo XIV, como el relicario de san Simón, san Judas, san Gregorio y Nicolás; el de san Pedro y san Pablo y el de san Esteban y san Blas, además de un lignum crucis y una espina de la corona de Cristo, todos ellos en la parroquia de san Pedro de la Rúa. ${ }^{18}$ Mientras que en la parroquia de san Miguel de Estella se encuentra el relicario de los santos Inocentes. ${ }^{19}$

Generalmente los relicarios, capsae, eran de materiales preciosos de acuerdo con el "tesoro" que contenían. En algunos casos estos relicarios tendrían algún tipo de inscripción epigráfica o una representación iconográfica que permitiera asociarlo con un santo determinado. Por otro lado, el uso de arcas, vasijas, cajas u otros recipientes "contenedores de reliquias" permitía salvaguardarlas tanto de los abusos cotidianos a los que se pudieran ver sometidas, como de peligros ocasionales pero de mayor relevancia. Resulta fácil deducir que, como norma general, el cuerpo del santo, sagrada reliquia, se mantenía oculto a la vista de todos aquellos que acudían a honrarlo. Una medida que parece aplicarse también cuando se trasladaban las reliquias de un lugar a otro. Alfonso $X$ en las Partidas recordaba la prohibición de sacar las reliquias de "aquellos lugares o estudiesen para mostrarlas con cobdicia de ganar con ellas algo". ${ }^{20}$ Este tipo de actuaciones queda ilustrado en las Cantigas de Santa María donde en una miniatura se representa a unos clérigos que llevan en procesión una arqueta con reliquias para "ganar dineros". ${ }^{21}$ Aunque también en cierto sentido, todas estas prescripciones eran un modo de recordar el

17 Osés Urricelqui, M. 2005. Documentación medieval de Estella (siglos XII-XVI) Pamplona: Gobierno de Navarra, doc. 127. Goñi Gaztambide, J. 19902001. Historia eclesiástica de Estella. T. 1, 95-104, Pamplona: Gobierno de Navarra. La parroquia alberga una cofradía en honor al santo desde el siglo XVI (p. 224). De esa misma fecha son la capilla y el retablo en su honor ( $p$. 261).

${ }^{18}$ En el primer inventario de los tesoros de esta parroquia realizado en 1582 se incrementa notablemente el número de reliquias: lágrimas de la Virgen, trozo del hábito de san Francisco, reliquia de san Bartolomé, san Fermín, santa Ana, santa Lucía, san Nicolás y cabellos de María Magdalena. Además de otras cuatro cajas redondas llenas de reliquias de santos.

${ }^{19}$ Heredia Moreno, C - Orbe, M. 1986. Orfebrería Navarra, Edad Media. I, 37 Pamplona: Gobierno de Navarra.

${ }^{20}$ Partida I, Título IV, ley CXXI.

${ }^{21}$ Menéndez Pidal, G. 1986. La España del siglo XIII leída en imágenes: 144 Madrid: Real Academia de la Historia. 
carácter sagrado de las mismas y la veneración con que debían ser tratadas.

El culto y la devoción a un mártir de los primeros siglos del Cristianismo, san Sebastián, en la ciudad de Tafalla tienen similares connotaciones al caso anterior. La devoción a san Sebastián se intensifica en los siglos XIV y XV debido a las oleadas de peste que azotan Europa y por supuesto también Navarra, enfermedad de la que el santo es considerado protector. Sin embargo, en esta ocasión no se trataba de ninguna reliquia corporal del santo patrón sino que la única "reliquia" existente es la boina del escultor Jehan de Lome a quien se le encargó una escultura del santo. ${ }^{22}$ A primera vista puede resultar extraño comprobar el respeto religioso y la sincera veneración que los hombres medievales demostraban hacia algunos objetos que carecían propiamente de alguna particularidad especial. Pero lo realmente sorprendente es como estos elementos materiales, vinculados de un modo u otro a la persona del santo, eran un cauce idóneo para su actuación milagrosa y por lo tanto potenciadores de una devoción popular. ${ }^{23}$

Por último hemos de hacer referencia a las reliquias de dos santos que junto a san Fermín, santas Nunilo y Alodia y san Marcial son las singularidades propias del culto en la cuenca de Pamplona. Se trata de san Guillén y santa Felicia. El culto a estos dos hermanos cuya devoción alcanzó una gran popularidad está localizado en Labiano y Obanos, villa esta última donde convergen la ruta jacetana y francesa que se dirigen hacia Santiago y lugares donde reposan sus restos. En Labiano se veneran las reliquias de la santa al menos desde 1480, mientras que las de san Guillén en Obanos es más tardía (1640) cuando la ermita de Arnotegui, cercana a esta localidad, se la denomina de san Guillermo, año en el que también se documenta la costumbre de pasar agua por la cabeza del santo. ${ }^{24}$

El argumento del relato hagiográfico arranca de finales de la Edad Media aunque a lo largo de los siglos ha sufrido una transformación oral que finalmente se plasma en varias versiones literarias de mayor o menor extensión. Según parece a finales del siglo $\mathrm{XI}$, la princesa Felicia, hija de los duques de Aquitania, peregrinó a Santiago de Compostela y en el transcurso de esta romería decidió

${ }^{22}$ Hasta 1667 no se trae de Roma la reliquia de San Sebastián donación de D. Sebastián Montero de Espinosa.

${ }^{23}$ El culto a este santo en la villa navarra ha sido estudiado en profundidad por Marcotegui, B. 2004. "Algunos fundamentos históricos del culto a san Sebastián en Tafalla", en Cuadernos de Etnología y Etnografía de Navarra, n. 79, 63-84, Pamplona: Universidad de Navarra.

24 Jimeno, R. 2003: 243. 
consagrar su vida a Dios alejándose de la corte de sus padres. De este modo se retiró a la vida consagrada en Navarra, pero su hermano Guillermo, de vida más pendenciera fue en su búsqueda. La resistencia de Felicia a marcharse llenó a Guillermo de ira y enajenado mató a su hermana que muere como virgen consagrada en fama de santidad. Arrepentido Guillermo decidió emprender la misma peregrinación a Santiago para expiar su terrible pecado y a su vuelta decidió vivir como ermitaño en el altozano de Arnotegui donde a su muerte se veneraron sus restos. ${ }^{25}$

Evidentemente, el camino de Santiago que en si mismo es una ruta trazada por la devoción a las reliquias contribuyó al desarrollo de otras devociones ligadas a reliquias como el caso que acabamos de analizar o como por ejemplo el arca santa de Oviedo. Además cabe pensar que por esta vía pudieran llegar nuevas reliquias a la Península. El propio culto al santo apóstol se introdujo en Navarra entre los siglos IX y XIII. La tradición ha situado al santo visitando Pamplona, Tudela, Fustiñana y Andosilla cuando vino a evangelizar tierras hispanas. No obstante, la historiografía ha desmontado la existencia de esta predicación por la Península y de un culto anterior a la mitad del VIII. En cuanto a sus reliquias tan sólo conocemos una en la cuenca de Pamplona, situada en la nueva parroquia del burgo nuevo de san Nicolás. El primer templo románico se incendió en 1222 y sobre sus ruinas se erige uno gótico consagrado por el obispo de Burgos Mauricio en 1231. La reliquia del apóstol fue depositada en el interior del altar, como era costumbre, junto con las de santa María Magdalena y santa Anastasia, el día de su consagración. Este dato lo trasmite el historiador jesuita del siglo XVII, José Moret, pero la lápida con la inscripción latina que daba esta referencia no se conserva, dato que no extraña debido a las numerosas remodelaciones que ha sufrido esta iglesia desde las fechas en que escribía este analista del reino. ${ }^{26}$

\section{LAS RELIQUIAS DE LOS SANTOS OBISPOS}

La Antigüedad cristiana había legado al mundo medieval tres arquetipos de santos: el mártir, el monje y el obispo. Este último estado se presentaba más bien como una función santa que requería de algún otro elemento, como el martirio o la ascesis que la completase y le confiriera la santidad. El obispo combinaba la vida activa, el servicio de la palabra, con la contemplativa, la oración, presentando un nuevo modelo de espiritualidad monástica adaptado a la acción pastoral.

25 Jimeno, R., 2002. San Guillén y santa Felicia. Los santos del misterio: 7-19 Pamplona, Gobierno de Navarra.

26 Jimeno, R. 2003: 236-238. 
Este rasgo queda revelado en la vida de san Martín de Tours, redactada por Sulpicio Severo, donde su ascesis monástica, vivida antes de ejercer el cargo episcopal, es la que hace de Martín un prototipo de santidad episcopal. La devoción al obispo tuvo una rápida extensión por todos los valles del territorio nuclear navarro, especialmente por la cuenca de Pamplona. El culto a este santo comenzó poco después de su muerte en el año 397 y fue patrocinado por la corte merovingia desde donde se divulgaron sus reliquias por toda la Europa Occidental. ${ }^{27}$ En la Península conocemos su devoción en tiempos de los visigodos, que la mantienen desde la época del reino de Tolouse. El nombre del santo aparece como hagiotopónimo de varias localidades navarras como san Martín de Urzainqui, en el valle del Roncal, donde se conserva un relicario de plata con sus reliquias de comienzos del siglo XV. Esta pieza anterior a 1423 parece haber sido elaborada en Pamplona en el burgo de san Cernin según indica su inscripción. La iglesia que cobija este tesoro es de mediados del siglo XIII y en 1425 el papa Martín V mandó al abad de Irache para que a petición del monarca se anexionara, junto a otras iglesias parroquiales, al priorato de la Orden de san Juan de Jerusalén. ${ }^{28}$

Un esquema hagiográfico similar del santo obispo franco es el que encontramos tanto en la vida de san Fermín como en la vida de san Saturnino. Los datos biográficos de este último los trasmite la Passio Saturinini (420-430). Saturnino, obispo de Tolouse, que vive en la segunda mitad del siglo III había sido el evangelizador de toda la región del Garona. Sus deseos de misión en tierras ultrapirenaicas hacen que envíe a su discípulo Honesto a predicar a los habitantes de Pamplona. Más tarde Saturnino llegará a Pamplona y a él se le atribuye la conversión en masa del pueblo y el de la familia senatorial de Firmo a la que pertenecía el joven Fermín. Poco después a su regreso a Tolouse recibe el martirio, atado a un toro su cuerpo fue arrastrado por las escalinatas del capitolio tolosano.

Aunque algunos hablan de una basílica del siglo IV dedicada al santo obispo mártir en Pamplona, lo cierto es que hasta finales del siglo XI no se inicia la construcción de una iglesia románica que será el centro neurálgico de este burgo que se fue repoblando de aportes ultrapirenaicos. La personalidad del nuevo vecindario está marcada por sus gentes, su origen, su régimen jurídico, las actividades económicas y monopolios comerciales, y su lengua, el occitano. Detrás de este proceso repoblador está la figura del obispo don Pedro de Roda y los privilegios otorgados por el rey pamplonés. El proceso de crecimiento del burgo se consolidó en 1129 cuando Alfonso I el Batallador otorga el fuero de Jaca.

\footnotetext{
27 Ibídem: 218.

${ }^{28}$ Heredia Moreno, C - Orbe, M. 1986: 55.
} 
La propia advocación de la parroquia, san Saturnino, quizás pudo deberse al obispo Pedro de Roda quien mantenía cordiales relaciones con los canónigos tolosanos, consultados para la reforma del cabildo pamplonés y a quienes en 1084 les donó la iglesia de Artajona donde alzarán un templo en honor de san Saturnino. ${ }^{29}$ Es muy probable que el obispo tomara esa decisión al regresar de Tolouse en 1096 cuando consagra junto a Urbano II y otros prelados la catedral de Saint-Sernin. Además a este prelado se le atribuye la repoblación de Pamplona pues por su iniciativa directa se fundan dos nuevos burgos: san Cernin y san Nicolás. El primero de ellos situado fuera de las murallas se repuebla con gentes francas que disfrutaron de generosos privilegios. ${ }^{30}$

La iglesia románica sufrió algunos destrozos en la guerra de la Navarrería de 1276 por lo que al año siguiente se emprendió su reconstrucción que finalizará hacia 1297. En esta iglesia-fortaleza se conserva un relicario de san Saturnino que contiene el pulgar del mártir pues el brazo de plata es un añadido del Barroco. Según parece fue una donación de Carlos III como indican las armas del monarca repetidas en los lugares más destacados del basamento. En 1412 los reyes de Navarra don Carlos y doña Leonor fundan seis aniversarios perpetuos en la iglesia de San Cernin, a la que declaran profesar singular devoción y para ello dejan varias casas que tienen en el barrio del portal de la judería de Pamplona.

A continuación hemos de hacer referencia a otro santo obispo cuyas reliquias se encuentran custodiadas en el ya mencionado monasterio de Leire. Se trata de san Marcial, que aparece mencionado junto a las mártires oscenses y el abad Virila en la documentación del cenobio desde la segunda mitad del siglo XI. En concreto el primer documento es del 27 noviembre de 1064. Quizás sea en torno a esta fecha cuando llegaron las reliquias del santo a este monasterio pues en un documento anterior, del 15 de junio de ese mismo año, tan sólo se nombra a las santas Nunilón y Alodia y al abad Virila. ${ }^{31}$

Las reliquias podían corresponder al obispo fundador de la sede de Limoges san Marcial del siglo III aunque de este santo no se poseen datos históricos fidedignos y su leyenda hagiográfica se elabora en el siglo X. Pero también podían ser del mártir cordobés del mismo nombre cuyo culto se documenta en la Bética durante el periodo hispano-godo.

29 Jimeno, R. 2003: 71-75. Aunque la advocación que aparece en la documentación hasta 1720 es san Cernín.

30 Irurita Lusarreta, M. A. 1959: El municipio de Pamplona en la Edad Media. Pamplona. Ayuntamiento de Pamplona.

${ }^{31}$ Martín Duque, A. 1983: doc. 74. 
San Eulogio relata que su sepulcro está junto al de sus compañeros Fausto y Jenaro en Córdoba. Como es sabido san Eulogio envió las reliquias de san Zoilo y san Asciclo al obispo pamplonés Wilesindo en el año 848. Casualmente estos mártires cordobeses acompañan a san Marcial en la quinta estrofa del himno a los mártires de Zaragoza de Prudencio. Es probable que en el siglo IX Leire adquiriese sus reliquias y que con el paso del tiempo se encargaría de rodear de un halo legendario y de difundir su devoción. Fuera de este núcleo no encontramos otras referencias por lo que su presencia obedece a unos deseos de enriquecer cultualmente este centro religioso.

Finalmente, entre los santos obispos con un culto destacado en el reino pamplonés se encuentran las reliquias de otro obispo extranjero pero cuya acción milagrosa desencadenó una fuerte devoción popular: San Gregorio Ostiense. Según cuenta el relato hagiográfico, hacia 1039 la Rioja y la ribera de Navarra se encontraban asoladas por una gran plaga de langostas. La desesperación de los navarros llevó a pedir ayuda al papa Benedicto IX, quien tras una revelación milagrosa, decidió enviar a un hombre justo con fama de santidad como era Gregorio, obispo cardenal de Ostia. Este prelado romano llegó a estas tierras donde permaneció unos cinco años y tras su predicación desapareció milagrosamente la plaga e incluso muchos musulmanes se convirtieron. Gregorio fallece en 1040 en Logroño y sus restos mortales depositados a lomo de una caballería, un recurso que se arbitra frecuentemente en los relatos hagiográficos para decidir donde debía enterrarse, se detuvieron primero en Mués, Sorlada y la última vez en el alto de Piñalba, en el valle de Berrueza, donde fue enterrado. No obstante, cuenta el relato que su memoria cayó en el olvido hasta la invención milagrosa de sus reliquias por los obispos de Pamplona y Bayona, Pedro Ximénez y Sancho Axco, a mediados del siglo XIII. A raíz del sorprendente hallazgo, rodeado de todos los detalles hagiográficos que volvían a confirmar la santidad del protagonista, se levantó una nueva ermita donde fueron veneradas las reliquias del santo obispo italiano. De mediados del siglo XIV son los primeros estatutos conservados de la cofradía en honor al santo en la Berrueza. A partir de entonces su culto se extendió por toda la Península, los textos hagiográficos del siglo XVII narran numerosos milagros atribuidos a la intercesión del santo, y se le considera como el santo protector de los agricultores que seguían la devota costumbre de pasar el agua con la que regarían sus campos por delante de sus reliquias. Actualmente se conservan en un relicario barroco que es una cabeza de plata así como un arca fabricada en $1610 .^{32}$

32 Jimeno, R. 2005. El remedio sobrenatural contra las plagas agrícolas hispanas: estudio institucional y social de la cofradía y santuario de san Gregorio Ostiense siglos XII-XIX.p. 43-44. Sorlada (Navarra): Cofradía de san Gregorio Ostiense. 


\section{LAS RELIQUIAS CRISTOLÓGICAS}

Evidentemente, el culto a las reliquias no está circunscrito a los santos y santas del Paraíso, pues también encontramos en Navarra numerosas reliquias relacionadas directamente con el Hijo de Dios, Jesucristo y su madre, Santa María, que sin duda tenían tanto o más valor espiritual que las analizadas hasta ahora. Se trata de una devoción particularmente floreciente en los siglos bajomedievales. Es cierto que entre estas reliquias no cabrían a priori aquellas que podríamos denominar corporales, pues con la Resurrección y Ascensión de Jesús a los cielos y la Asunción de María en cuerpo y alma, quedaba anulada esa posibilidad. No obstante cabe señalar la aparición de sorprendentes reliquias corporales relacionadas con la infancia de Jesús (dientes de leche, el prepucio...). Sin embargo y en relación al cuerpo de Cristo será la Eucaristía la que ejerza una especial atracción a partir del siglo XII, en cuanto supone la presencia real de Cristo entre los hombres.

El grupo de reliquias cristológicas que florecen en los siglos medievales hasta alcanzar cantidades sorprendentes son todos aquellos objetos materiales que resultaron santificados por contacto con el Hijo de Dios, en especial los relacionados con la Pasión. $Y$ de todas ellas, sin lugar a dudas el primer puesto lo ocupa la cruz que sostuvo el cuerpo herido y flagelado de Cristo hasta su muerte. En este caso el objeto quedó santificado por contacto directo pues fue el patíbulo del Señor. Sin embargo, al mismo tiempo no hemos de olvidar que este madero encerraba un misterio de una dimensión trascendente, la Redención, Dios hecho hombre que muere para la salvación de todos, una de las claves principales del cristianismo. ${ }^{33}$

Según la tradición la reliquia del lignum crucis fue hallada por santa Elena, la madre del emperador Constantino, en el lugar del sepulcro de Jerusalén donde quedó custodiada. Ahí se erigió una basílica, dado el estado lamentable en el que se encontraba el santo sepulcro, cuyas obras no terminaron hasta el año 335. La leyenda de invención de la Cruz, donde no deja de estar presente el carácter milagroso, pues se reconoce la verdadera cruz entre otros fragmentos gracias a la curación de una moribunda, se configura en las últimas décadas del siglo IV en el oriente griego y hacia el año 400 se expande por Oriente y Occidente. ${ }^{34}$

${ }^{33}$ García de la Borbolla, A. 2005 "El culto y la devoción al lignum crucis en los reinos occidentales de la Península Ibérica (VII-XV)" en Pecia.

Ressources en médiévistique, vol. 8/11, 565-600.

34 Leclercq, H. 1948 «Croix inventio et exaltation de la vraie croix » en Dictionnaire d'archeologie chretienne et de liturgie, T.III, 3131-3138. París: 
La devoción fue enorme y se extendió muy rápido tal y como lo demuestran los numerosos templos consagrados en su honor y la multiplicación de relicarios con fragmento de la misma. Según parece una parte de la cruz, revestida de láminas de oro y piedras preciosas, se quedó en Jerusalén, pero otra fue llevada a Constantinopla por la madre del emperador Constantino. En el año 614 con la conquista de Jerusalén por los persas, la reliquia no desapareció sino que permaneció oculta. Después, cuando Heraclio reconquista la ciudad, también se procede a una nueva redistribución aunque con la invasión musulmana (635) es trasladada en su totalidad a Constantinopla, sin saber a ciencia cierta en que lugar se depositó, si en el Palacio Real o en santa Sofía. Estas reliquias del tesoro de Constantinopla se diseminarán por Europa occidental tras la conquista y el pillaje de la ciudad por los cruzados en el año $1204 .{ }^{35}$ Entonces la Vera Cruz se llevó a Roma y desde allí los papas enviaron fragmentos a diversos reinos de Occidente. Al mismo tiempo, numerosos fragmentos del leño santo fueron traídos por los cruzados a Occidente, destinados a engrosar los tesoros de las catedrales y monasterios. Para ello se elaboraron magníficas estaurotecas en forma de cruz patriarcal o doble que contenían la reliquia.

De manera que estos tres enclaves, Jerusalén, Constantinopla y Roma serán los principales puntos de difusión de esta reliquia, en cierto sentido podemos hablar de una devoción ecuménica compartida por toda la Cristiandad oriental y occidental

En la Península Ibérica la devoción a la Cruz Verdadera está testimoniada desde época visigoda y tras el intervalo que supuso la invasión musulmana se vuelve a atestiguar su culto. ${ }^{36}$ La devoción a la

Letouzey et Ané. Además hay otras dos leyendas, una que atribuye la invención a Potociné, mujer del vice emperador Claudio, durante el reinado de Tiberio y la del judío Judas Ciriaco, converso que llega a ser obispo de Jerusalén. El episodio del milagro se introduce hacia el año 400-y lo recogen Paulino de Nola, Sulpicio Severo y Sozomeno.

35 No obstante cuando los primeros cruzados entraron en el santo Sepulcro la cruz no estaba allí, aunque "sorprendentemente" en el plazo de una semana la hallaron. Se trataba de una nueva invención, un hecho apócrifo. Una vez más se convirtió en la reliquia más preciosa, símbolo del reino recién instaurado de los cruzados, que será custodiada por los canónigos del Santo Sepulcro y que incluso se llevaba al campo de batalla para proteger a los cristianos de los enemigos.

${ }^{36}$ Frolow, A. 1965. Les reliquaires de la vraie croix : 184 París: Institut Français d'Etudes Byzantines. Una de las primeras noticias en relación con la presencia de tan insigne reliquia en nuestro solar hispano se remonta a finales del siglo VI. Al parecer hacia el año 599 llega a Toledo, capital del reino visigodo, un relicario con el fragmento de la verdadera cruz junto con cabellos 
reliquia de la santa Cruz permanecerá entre los cristianos tal y como lo manifiestan las cruces relicarios de Oviedo o los himnos en honor a la Vera Cruz. Al mismo tiempo se iniciará un proceso de adquisición de esta reliquia por parte de los principales centros de poder o puntos estratégicos de los reinos cristianos del Norte.

En el caso del reino de Navarra, la llegada del lignum crucis a la catedral de Pamplona, fue bastante tardía, aunque no era la primera reliquia de este tipo en el reino. ${ }^{37}$ Así por ejemplo merece destacarse el relicario Ilamado del Santo Sepulcro, fechado a mediados del siglo XIII, y que contiene numerosas reliquias procedentes de Tierra Santa y relacionadas con la Pasión de Cristo. ${ }^{38}$ En cuanto al lignum crucis las circunstancias que rodean su advenimiento están relacionadas con una embajada diplomática por la que se pretendían favorecer acuerdos, solicitar ayudas o reforzar relaciones entre Oriente y Occidente. La reliquia fue un regalo del emperador Miguel Paleólogo a Carlos III en el transcurso del viaje que emprende el primero a finales de 1399. El emperador acude ante los reyes de Francia, Inglaterra, Aragón, Castilla, Navarra y al príncipe de Moscovia entre otros, así como al papado de Roma y Avignon, insistiendo en todas sus misivas en el mismo problema: la necesidad de auxilio ante el avance de los turcos otomanos. De este modo, el emperador tras su periplo por algunas ciudades italianas se dirige a Francia, que vive un momento de tregua en la Guerra de los Cien Años. Su estancia en París se prolongará dos años en razón de la esperanza albergada de recibir ayuda de Carlos VI. Y desde la corte francesa, enviará al caballero Alejo de Verna, como embajador ante

de san Juan Bautista. Se trataba de un regalo que el pontífice Gregorio el Grande, tal y como cuenta en sus Epístolas, quiso hacer al monarca Recaredo que había abrazado la fe católica abandonando la herejía arriana. Esta primera reliquia debió permanecer en Toledo durante toda la época visigoda, pero más tarde tal y como nos cuenta el obispo ovetense Pelayo pasó a estar custodiada en el Arca Santa de Oviedo, quizás como consecuencia de la invasión musulmana en la Península Ibérica y el consiguiente movimiento de reliquias hacia el norte.

37 Goñi Gaztambide, J. 1965, Catálogo del Archivo de la Catedral de Pamplona, doc. 1621, Pamplona: Príncipe de Viana.

${ }^{38}$ Martínez de Aguirre, J. 2002, "Los relicarios góticos del santo Sepulcro (siglo XIII) y de la santa Espina (XV) de la catedral de Pamplona" en Príncipe de Viana, 63. Pamplona: Gobierno de Navarra. Y Martínez de Aguirre, J. 2006, "Nuevos documentos sobre el relicario del Lignum crucis de la catedral de Pamplona" en Cuadernos de la Cátedra de Patrimonio y Arte Navarro, (1), 135150. Este relicario fue abierto en 1993 realizándose un inventario de las reliquias contenidas. Vid. Omeñaca Sanz, J. Ma. 2002, "Inventario de las reliquias contenidas en el relicario del santo Sepulcro de la catedral de Pamplona" en Príncipe de Viana, 63. 287-294. Pamplona: Gobierno de Navarra. 
distintos monarcas del orbe cristiano, entre ellos Martín I de Aragón y Carlos III de Navarra, así como al papa Benedicto XIII en Avignon.

Entendemos que el emperador bizantino en su misión por Occidente decidió que debía honrar a estos príncipes con presentes dignos del prestigio y la antigüedad de Constantinopla. Además durante los siglos bajomedievales, la capital del Imperio griego seguía siendo un centro importante de difusión de esta reliquia, que en esta ocasión va a ser utilizada como un instrumento de la política imperial. Así ante la imposibilidad de ofrecer ricos presentes en oro, seda o púrpura, entregaría otros tesoros muy estimados entre los cristianos: las reliquias de la Pasión. ${ }^{39}$ De manera que Carlos III recibió un fragmento del lignum crucis y de la túnica del Señor, acompañados de una carta que el mismo emperador suscribe el 30 de agosto de $1400 .{ }^{40}$

Una vez llegado el embajador del emperador, Alejo de Verna, a la capital del reino navarro, las reliquias no fueron recibidas por el obispo de Pamplona, Martín de Zalba, que en esas fechas se encontraba en Avignon apoyando el partido de Pedro de Luna. De manera que fue el confesor del rey, Fray García de Eugui, obispo de Bayona el encargado de acogerlas con toda la solemnidad debida. La ceremonia, el día de la Epifanía de 1401, puede ser reconstruida gracias al acta notarial de Sancho de Oteiza. Según el notario, las reliquias fueron paseadas por el claustro de la catedral y al acto asistió el rey, numerosos nobles como el hermano natural del rey Leonel de Navarra, don Francisco de Villaespesa, canciller, y don Beltrán de Lacarra, chambelán, así como el cabildo, el clero y las gentes de la ciudad. ${ }^{41}$ Finalmente, la reliquia del lignum crucis fue depositada en un relicario cuya composición no describiremos pero que al parecer fue modificado a comienzos del siglo $\mathrm{XV}$ para incorporar así estas reliquias. ${ }^{42} \mathrm{~A}$ partir de entonces, el silencio de las fuentes sobre el culto a esta reliquia es casi total, y contrasta con

${ }^{39}$ Benedicto XIII recibe un trozo del manto del Señor, acompañado de un documento que garantizaba la autenticidad de la reliquia; Martín I, un trozo del manto del Señor y la esponja utilizada para darle de beber a Cristo en la cruz.

40 Arigita, M. 1935. «El lignum crucis de la catedral de Pamplona» en Boletín de la comisión de monumentos históricos y artísticos de Navarra, Tomo $\mathrm{XIX}, 221$. Pamplona. Donde se dice: particulam ligni vere et salutifere crucis in qua salvator noster perpendit. Dedimus etiam eidem paruam particulam vestimenti nostri Redemptoris quasi blauis coloris ex eo scilicet vestimento cuius fimbriam tangens mulier a fluxu sanguinis sanata est.

41 Vera Idotate, G. 1931. Navarra y las cruzadas. 183 Pamplona: Aramburu.

42 Heredia Moreno, C - Orbe, M. 1986: 34. Martínez de Aguirre, J, 2006, "Nuevos documentos sobre el relicario del Lignum Crucis de la catedral de Pamplona" en Cuadernos de la cátedra de Patrimonio y Arte Navarro, 1: 135150. Pamplona: Universidad de Navarra. 
la devoción que recibió casi dos siglos antes la llegada también desde Francia de otra reliquia de la Pasión: la santa Espina. ${ }^{43}$ Por otro lado, las esperanzas del emperador salieron frustradas, las ayudas fueron modestas, y en 1401 regresó a su patria. En 1423 el sultán sitió Constantinopla y dos años más tarde moría Manuel Paleólogo.

Sin embargo, está no será la única reliquia del lignum crucis existente en el reino navarro. Estos pequeños trozos de madera, a veces simplemente astillas de la Vera Cruz, serán el tesoro más preciado que con los ojos de la fe trascendía las insignificantes dimensiones materiales. Tenemos noticia de un relicario de plata fechado hacia la segunda mitad del siglo XIV, conservado en la abadía de Roncesvalles y conocido con el nombre del "Ajedrez de Carlomagno" dada su disposición similar a un tablero de damas y a la errónea atribución a Carlomagno mantenida durante mucho tiempo. ${ }^{44}$ Este relicario, fabricado en un taller de Montpellier tal y como muestra la marca lateral en caracteres góticos, aparece dividido en casillas que contenían reliquias envueltas en lienzos, con sus correspondientes etiquetas para su identificación. Una pequeña cruz de madera en la casilla del medio de la fila superior parece ser un lignum crucis. El origen de esta pieza debe entenderse como una consecuencia de las continuas relaciones de esta ciudad francesa con los reinos hispanos entre los siglos XIII y XIV. La villa se incorporó al reino de Aragón a raíz del matrimonio de Pedro II con María de Montpellier. Posteriormente, a mediados del siglo XIV, Juan III de Mallorca la vende a Felipe IV de Francia. Por otro lado, desde el siglo anterior está documentada que la colegiata de Roncesvalles poseyó una encomienda en Montpellier conservada hasta 1364 y que al año siguiente de su extinción, el señorío de la villa fue adquirido por Carlos II, manteniéndose en la dinastía Evreux hasta 1382. Estas circunstancias, así como la fama de los talleres de esmaltadores de la ciudad francesa, pudieron impulsar a la Colegiata a encargar esta pieza de tal categoría. Finalmente, la reunión en el mismo relicario de reliquias de diferente procedencia es interesante pues nos habla de la convergencia de cultos,

${ }^{43}$ Esta reliquia fue el regalo que envió san Luis de Francia a su sobrino Teobaldo de Champaña, con motivo de su boda con su hija Isabel (1255) y de su coronación como rey de Navarra (1258). La increíble devoción que gozó esta reliquia se manifiesta por el hecho que hacia 1264 se celebrara una festividad consagrada a la santa Espina en la catedral de Pamplona. En el día de esta festividad se daba una pitanza a los canónigos de la catedral sufragada por la Hacienda Real. Incluso el papa Urbano IV concede indulgencia a aquellos que visitaran la catedral el día de la festividad de la santa Espina. El relicario que contiene este sagrado tesoro es del siglo XV pero anterior a 1423 realizado en algún taller de Pamplona como indica el cuño con la divisa del burgo de san Cernin que se suprime en la disposición XVI del Privilegio de la Unión dado en 1423 por Carlos III, sustituyéndola por otra.

${ }^{44}$ Heredia Moreno, C - Orbe, M. 1986: 41-43. 
de la disponibilidad en el mercado de reliquias y la capacidad de adquisición, así como de la espiritualidad de aquella institución.

Por último, y en este mismo marco geopolítico, tenemos el relicario en plata del Lignum Crucis de san Miguel de Estella. Esta estauroteca con caracteres iconográficos del gótico procede de un taller navarro y se data de la primera mitad del XIV. No sabemos mucho más de su origen, aunque sí de su trayectoria, pues al parecer dado los escasos medios de la parroquia de san Miguel, en 1489 empeñó el Lignum crucis por 150 florines a los parroquianos de san Pedro de Estella que les habían prestado 10 quintales de cobre para fundir una campana. ${ }^{45}$ Probablemente, los parroquianos y el clero de esta parroquia intentaron recuperar esta reliquia lo antes posible, y quizás así se entiendan los muchos donativos que recoge el libro de mandas pías de la parroquia. ${ }^{46}$

Los fluidos contactos entre Oriente y Occidente a través de los cruzados y peregrinos dieron lugar en muchas ocasiones a la elaboración de episodios legendarios relacionados con esta reliquia como es aquel de la Virgen de Jerusalén de Artajona (Navarra). La leyenda que envuelve esta imagen se remonta al año 1099 momento de la primera cruzada. Se trata de un relato recogido en un apócrifo del siglo XVI con el objeto de dar autenticidad a la reliquia del lignum crucis que se encuentra en el interior la imagen mariana. Al parecer a fines del siglo XI, cierto infanzón de Artajona, Saturnino Lasterra, comprometido con la rica y bella Felicia tuvo que huir del reino por un periodo cinco años. A su vuelta le informaron que Felicia había sido raptada por los musulmanes. El joven enloquecido comienza su búsqueda y parte a Oriente por si la pudiera encontrar cautiva. De este modo se enrola en la cruzada "popular" de Pedro el Ermitaño junto al conde Sancho Ramírez y Fortún Sánchez y otros caballeros de Navarra. En la víspera del asalto a Nicea se le aparece al infanzón su prometida Felicia con un aura divina y tras confirmarle que ha muerto le anima a luchar por los Santos Lugares. Y eso es lo que hizo Saturnino adquiriendo un gran prestigio militar por su valor. Una vez terminada la contienda, Godofredo de Bouillon, rey de Jerusalén y defensor del Santo Sepulcro, le distingue como el más valiente y le pide que elija la gracia más preciada. El caballero solicita la efigie que el rey ha llevado en el arzón de su caballo durante la batalla. Al parecer sigue contando el relato, se trataba de una figurilla tallada por Nicodemo, discípulo de Jesús, que guardaba unas misteriosas fórmulas cabalísticas relacionadas con el Templo de Salomón. Finalmente,

${ }^{45}$ Goñi Gaztambide, J. 1986. «La capilla de los Eulate en san Miguel de Estella» en Homenaje a Lacarra, I, Príncipe de Viana, Anejo 2, tomo I: 294. Pamplona. Gobierno de Navarra.

46 Ibídem: 298. En el segundo cuaderno que finaliza en el año 1525 se anotan varias donaciones con la siguiente donación: "para ayuda de la cruz". 
Saturnino vuelve a Artajona con la imagen de cobre dorado y esmaltado que tenía algunas reliquias en su interior entre ellas un lignum crucis. ${ }^{47}$

El fundamento histórico de esta leyenda fue estudiado por el erudito José Jimeno Jurío en un artículo donde en primer lugar analiza el pergamino redactado para simular una donación que no existió, y que se esconde en la imagen. Se trataba de una falsificación o copia del siglo $\mathrm{XVI}$ hecha por un escribano local con escasos conocimientos del latín, aunque el texto original debió escribirse en Francia. En segundo lugar, el autor del artículo destaca la ausencia del apellido Lasterra en la documentación de Artajona hasta la segunda mitad del siglo XIII. Además en los motivos heráldicos del escudo primitivo del linaje no hay alusión alguna a la conquista de Jerusalén ni a la donación de la imagen, ni tampoco se presenta como recurso para obtener la hidalguía. ${ }^{48}$

Por otro lado, se ha de tener en cuenta el análisis artístico de la imagen. Se trata de una pieza del siglo XIII que presenta una gran influencia de los talleres de Limoges, aunque hay que señalar que a finales del siglo XIII en España hay algunos talleres especializados en producir imágenes esmaltadas similares. Se observa que el basamento presenta las patas arqueadas por lo que pudo ser una Virgen de las batallas que se llevaba en el arzón del caballo. Además el hueco abierto y protegido por una portezuela en el trono donde esta sentada la imagen lleva a pensar que sí estamos ante una Virgen relicario. ${ }^{49}$

También en el reino Navarro tenemos otro episodio legendario forjado en torno a la reliquia del lignum crucis de Murugarren en el valle de Yerri, una encomienda de la Orden templaria. Al parecer una joven estellesa en vísperas de su boda fue raptada en el transcurso de una aceifa musulmana. El novio, un infanzón del lugar, noble pero sin fortuna, no pudo reunir el rescate exigido. De modo que desconsolado acude a rezar a la imagen de Nuestra Señora de los Huertos, encomienda templaria en el valle de Yerri. En la soledad de la iglesia, el caballero descubre un lignum crucis cubierto de oro y piedras preciosas. Entonces, lo toma y lo cambia por la libertad de su dama. Pero cuando en la ceremonia nupcial el sacerdote les acerca la reliquia para que la besen los novios, sorprendentemente ésta se retira de sus labios, quien

47 Martín Duque, A. (dirg) 1991. Camino de Santiago en Navarra: 106, Pamplona: Gobierno de Navarra.

48 Jimeno Jurío, J. M ${ }^{a}$ 1966. "Historia y leyenda en torno a la Virgen de Jerusalén de Artajona" en Príncipe de Viana, vol. 27, 80. Pamplona: Gobierno de Navarra. Fue descubierto en 1584 por el pintor Beltrán de Otazu a quien se lo robó su criado Juan de Segura que enfermó y devolverá a los dos años el pergamino. Por lo tanto, el pergamino fue colocado dentro de la imagen entre 1503 y 1584 aunque en el siglo XVIII se retoca la letra.

${ }^{49}$ Heredia Moreno, C - Orbe, M. 1986: 17 
sobrecogido y arrepentido confesará su sacrílego hurto. Sin embargo, el sacerdote le responde que esa cruz nunca ha salido del templo. El joven infanzón impresionado por el milagro peregrina a Compostela buscando el perdón y luego profesa como caballero de Temple, muriendo en Jerusalén cerca del enclave de la Cruz. ${ }^{50}$ En suma, cruzados, Jerusalén y las órdenes Templaria y Hospitalaria contribuyen a una nueva difusión por el Mediterráneo de esta reliquia en un contexto espiritual de creciente cristocentrismo, es decir, de contemplación y veneración de la humanidad de Cristo. Una piedad que se orientará en un primer momento hacia la Cruz y posteriormente hacia el sacramento de la Eucaristía.

\section{CONSIDERACIONES FINALES}

El punto de partida para entender la devoción a las reliquias es un presupuesto arraigado en el sentir del hombre medieval, su vibración con todo "lo santo", entendido como un producto derivado de lo divino. En la espiritualidad medieval donde juega un papel muy destacado el culto a los santos un elemento clave resulta ser la permanencia, la memoria, el recuerdo. Sin duda, esta perdurabilidad quedaba garantizada en la mente del hombre medieval si se asociaba a algún objeto material y sensible. De modo que los restos mortales del santo y el lugar donde se encontraban se convierten en el indicador más efectivo de su actual permanencia entre los hombres. Además estos elementos materiales, vinculados de un modo u otro a la persona del santo, eran un cauce idóneo para su actuación milagrosa.

Quizás a primera vista, la reliquia se puede considerar como un objeto sin valor intrínseco, pasivo y neutral. Pero desde una religiosidad que tiene como punto de partida la fe, estos objetos adquieren un significado primordial. Sin duda es el grupo de fieles quienes, reconociendo en ella la permanencia física del santo le conceden su especial consideración. Sin embargo, una espiritualidad mal entendida ocasionó con frecuencia numerosos excesos y usos poco correctos de estos sacros recuerdos a lo largo de los siglos medievales. Incluso a veces se obtenían por medios irregulares, como los robos o intercambios fraudulentos y engañosos. ${ }^{51}$ En consecuencia cada vez se hará mayor

${ }^{50}$ Martín Duque, A. (dirg) 1991: 100.

51 Así ante la proliferación de falsas reliquias, como el sagrado botín llegado a Europa tras la cuarta cruzada, el papado dirige su atención a este hecho y ordena que ninguna reliquia debía ser venerada sin el consentimiento del romano Pontífice. Para paliar tales efectos en el canon 62 del concilio lateranense de 1215 se establece la reserva papal sobre el derecho al culto de las nuevas reliquias: inventas autem de novo reliquias nemo publice venerari praesumat, nisi prius auctoritate Romani Pontificis fuerint approbate. $\mathrm{Y}$ unos 
hincapié en demostrar la veracidad de la reliquia, buscando pruebas directas como alguna inscripción, o indirectas -la tradición oral, los inventarios de reliquias, los milagros o las donaciones- que la autentificaran.

De este modo, separada de un contexto específico una reliquia carece totalmente de significado y sólo desde la perspectiva de unas determinadas creencias colectivas y en el ámbito de la piedad, se puede llegar a comprender su función cultual. La trascendencia espiritual y religiosa de estos sagrados recuerdos ha recorrido siglos llegando hasta la sociedad actual donde aún se veneran y se celebran su culto. ${ }^{52}$

\section{BIBLIOGRAFÍA}

Arigita, M. 1935. «El lignum crucis de la catedral de Pamplona» en Boletin de la comisión de monumentos históricos y artísticos de Navarra, Tomo XIX. Pamplona

Arraiza Frauca, J. 2002. San Fermín, el santo, la devoción, la fiesta. Pamplona: Ayuntamiento de Pamplona.

Chiovaro, F. 1986. Histoire des saints et de la sainteté. París: Hachette. 11 vols.

Delehaye, H. 1933. Les origines du culte des martyrs. Bruselas: Societé des Bollendistes.

Fernández Catón, JM. 2003. "El culto de las reliquias: crítica hagiográfica, fuentes e historia" en Memoria Ecclesiae. 24.

Fernández Ladreda, 1988. Imaginería medieval mariana, Pamplona: Gobierno de Navarra.

Fortún, L. J. 1983. Leire, un señorío monástico en Navarra (siglos $X I-X I X)$. Pamplona: Gobierno de Navarra.

Frolow, A. 1965. Les reliquaires de la vraie croix. París: Institut Français d'Etudes Byzantines.

años más tarde, en 1234, Gregorio X recoge en sus decretales la necesidad de la autoridad papal para la aprobación del culto a un nuevo santo.

52 En el caso navarro el ejemplo más llamativo es la devoción a san Fermín. Pero cabría señalar también la reliquia de san Miguel que cada año abandonan su santuario y recorren todo el espacio geográfico de la comunidad Foral. 
García de la Borbolla, A. 2001. "La materialidad eterna de los santos. Sepulcros, reliquias y peregrinaciones en la hagiografía castellano-leonesa. Siglo XIII". Medievalismo. Boletín de la Sociedad Española de Estudios Medievales. 11: P. 9-31.

García de la Borbolla, A. 2002. La "praesentia" y la "virtus" de los santos en el mundo medieval: la imagen y función del santo a partir de la hagiografía castellano-leonesa del siglo XIII. Abadía de Silos Burgos: Studia Silensia, XXIV.

García de la Borbolla, A. 2005. "El culto y la devoción al lignum crucis en los reinos occidentales de la Península lbérica (VII-XV)" en Pecia. Ressources en médiévistique, vol. 8/11, 565-600.

García Rodríguez, C. 1966. El culto a los santos en la España romana y visigoda: Madrid: CSIC.

Goñi Gaztambide, J. 1965. Catálogo del Archivo de la Catedral de Pamplona, Pamplona: Príncipe de Viana.

Goñi Gaztambide, J. 1979. Historia de los obispos de Pamplona, Pamplona, I: Diputación Foral de Navarra.

Goñi Gaztambide, J. 1986. «La capilla de los Eulate en san Miguel de Estella» en Homenaje a Lacarra, I, Príncipe de Viana, Anejo 2, tomo I: 294. Pamplona. Gobierno de Navarra.

Goñi Gaztambide, J. 1994. "La veneración a santa María la Real", La Catedral de Pamplona, I, 25-33. Pamplona: Caja de Ahorros de Navarra.

Goñi Gaztambide, J. 1997. Colección diplomática de la Catedral de Pamplona (829-1243) Pamplona: Gobierno de Navarra.

Goñi Gaztambide, J. 1990-2001. Historia eclesiástica de Estella. Pamplona: Gobierno de Navarra.

Heredia Moreno, C - Orbe, M. 1986. Orfebrería Navarra, Edad Media. Pamplona: Gobierno de Navarra.

Herrman-Mascard, N. 1975. Les reliques des saints. La formation coutumière de un droit. París, Klincksieck.

Iribarren, S. 1912. Apuntes sobre la historia antigua de Estella. Sevilla: las Heras. 
Irurita Lusarreta, M. A. 1959: El municipio de Pamplona en la Edad Media. Pamplona: Ayuntamiento de Pamplona.

Jimeno Aranguren, R., 2002. San Guillén y santa Felicia. Los santos del misterio. Pamplona, Gobierno de Navarra.

Jimeno Aranguren, R. 2003. El culto a los santos en la cuenca de Pamplona, siglos V-XVI, Pamplona: Gobierno de Navarra.

Jimeno Aranguren, R. 2005. El remedio sobrenatural contra las plagas agrícolas hispanas: estudio institucional y social de la cofradía y santuario de san Gregorio Ostiense siglos XII-XIX, Sorlada (Navarra): Cofradía de san Gregorio Ostiense.

Jimeno Jurío, J. Ma 1966. "Historia y leyenda en torno a la Virgen de Jerusalén de Artajona" en Príncipe de Viana, vol. 27. Pamplona: Gobierno de Navarra.

Leclercq, H. 1948. "Croix inventio et exaltation de la vraie croix " en Dictionnaire d'archeologie chretienne et de liturgie, T.III, 3131-3138. París: Letouzey et Ané.

Marcotegui, B. 2004. "Algunos fundamentos históricos del culto a san Sebastián en Tafalla", en Cuadernos de Etnología y Etnografía de Navarra, n. 79 Pamplona: Universidad de Navarra.

Martín Duque, A. 1983. Documentación Medieval de Leire (siglos IX-XII). Pamplona: Gobierno de Navarra.

Martín Duque, A. (dirg) 1991. Camino de Santiago en Navarra. Pamplona: Gobierno de Navarra.

Martínez de Aguirre, J. 2002. "Los relicarios góticos del santo Sepulcro (siglo XIII) y de la santa Espina (XV) de la catedral de Pamplona" en Príncipe de Viana, 63. Pamplona: Gobierno de Navarra.

Martínez de Aguirre, J, 2006. "Nuevos documentos sobre el relicario del Lignum Crucis de la catedral de Pamplona" en Cuadernos de la cátedra de Patrimonio y Arte Navarro, 1: 135-150. Pamplona: Universidad de Navarra.

Menéndez Pidal, G. 1986. La España del siglo XIII leída en imágenes: Madrid: Real Academia de la Historia. 
Omeñaca Sanz, J. Ma. 2002. "Inventario de las reliquias contenidas en el relicario del santo Sepulcro de la catedral de Pamplona" en Príncipe de Viana, 63. 287-294. Pamplona: Gobierno de Navarra.

Osés Urricelqui, M. 2005. Documentación medieval de Estella (siglos XII-XVI), Pamplona: Gobierno de Navarra.

Pavón, J. y García de la Borbolla, A., 2007. Morir en la Edad Media: Valencia: Universidad de Valencia.

Pérez-Embid, J. 2002. Hagiología y sociedad en la España Medieval. Castilla y León (siglos XI-XIII). Universidad de Huelva

Vera Idotate, G. 1931. Navarra y las cruzadas. Pamplona: Aramburu. 